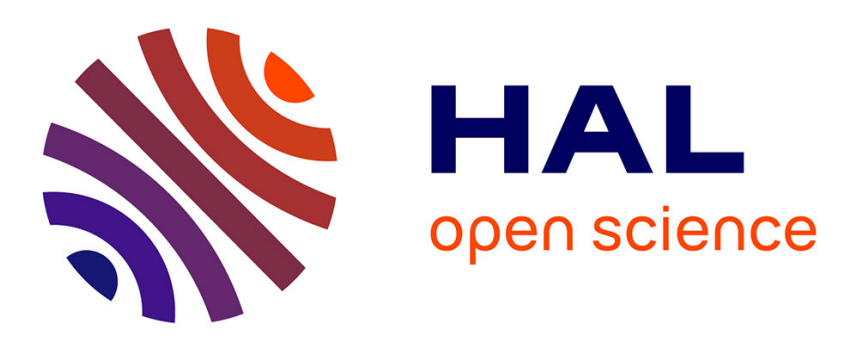

\title{
Inhibitory effects of sodium azide on microbial growth in experimental resuspension of marine sediment
}

\author{
Léa Cabrol, Marianne Quemeneur, Benjamin Misson
}

\section{To cite this version:}

Léa Cabrol, Marianne Quemeneur, Benjamin Misson. Inhibitory effects of sodium azide on microbial growth in experimental resuspension of marine sediment. Journal of Microbiological Methods, 2017, 133, pp.62 - 65. 10.1016/j.mimet.2016.12.021 . ird-01647866

\section{HAL Id: ird-01647866 \\ https://hal.ird.fr/ird-01647866}

Submitted on 7 Jan 2022

HAL is a multi-disciplinary open access archive for the deposit and dissemination of scientific research documents, whether they are published or not. The documents may come from teaching and research institutions in France or abroad, or from public or private research centers.
L'archive ouverte pluridisciplinaire HAL, est destinée au dépôt et à la diffusion de documents scientifiques de niveau recherche, publiés ou non, émanant des établissements d'enseignement et de recherche français ou étrangers, des laboratoires publics ou privés. 
Note

\title{
Inhibitory effects of sodium azide on microbial growth in experimental resuspension of marine sediment
}

\author{
Léa Cabrol ${ }^{\mathrm{a}, *}$, Marianne Quéméneur ${ }^{\mathrm{a}}$, Benjamin Misson ${ }^{\mathrm{b}}$ \\ a Aix Marseille Univ, Univ Toulon, CNRS, IRD, MIO UM 110, Mediterranean Institute of Oceanography, Marseille, France \\ b PROTEE, EA 3819, Toulon University, CS 60584-83041 Toulon, Cedex 9, France
}

\section{A R T I C L E I N F O}

Article history:

Received 30 November 2016

Received in revised form 22 December 2016

Accepted 22 December 2016

Available online 27 December 2016

\section{Keywords:}

Sodium azide $\left(\mathrm{NaN}_{3}\right)$

Inhibition

Sterilization

Microbial growth

Marine sediment

qPCR/cytometry

\begin{abstract}
A B S T R A C T
Sodium azide $\left(\mathrm{NaN}_{3}\right)$ was evaluated as inhibitor of microbial growth and activity in marine sediment resuspensions by monitoring the abundance of free-living and sessile bacteria using both flow cytometry and qPCR methods. Results show that $50 \mathrm{mM}$ of $\mathrm{NaN}_{3}$ strongly inhibits bacterial growth under natural and enriched resource conditions.
\end{abstract}

(C) 2016 Elsevier B.V. All rights reserved.
Microbial communities play key roles in biogeochemical cycles of contaminants, affecting their fate by degradation, (de)sorption, redox transformations, albeit often in a still poorly understood way. In order to identify clearly the role of microbial communities in contaminant dynamics (e.g. trace metal cycling and mobility) and to distinguish biological and physicochemical contributions, it is crucial to develop experimental incubations under controlled conditions, to enable comparison of biotic microcosms with abiotic controls (i.e. where microbial growth and activity have been inhibited). However, in the complex matrices of contaminated ecosystems, the sterilization method must be chosen cautiously in order not to interfere with abiotic drivers of contaminant dynamics.

Several chemical and physical methods exist to sterilize various kinds of materials, based on heat, chemicals, antibiotics, filtration or radiations. Among physical methods, steam sterilization through autoclaving is the most widespread technique but it has several drawbacks when focusing on contaminant fate, such as: disruption of the physical structure of soils and sediments (Ramsay and Bawden, 1983; Trevors, 1996); release of dissolved metals and nutrients (Quéméneur et al., 2016; Senko et al., 2008); desorption of organic compounds acting as possible metal ligands and modification of metal speciation (Egli et al., 2006). $\gamma$-irradiation is considered as an alternative technique, but it is generally less easily available, requires long stabilization times

\footnotetext{
* Corresponding author.

E-mail address: lea.cabrol@mio.osupytheas.fr (L. Cabrol).
}

(Ramsay and Bawden, 1983), and creates reactive redox agents that may induce abiotic reactions with metals (Trevors, 1996; Bank et al., 2008). Both $\gamma$-irradiation and autoclaving altered soil organic matter chemistry (functional group identity and abundance), thus affecting pollutant sorption, affinity and bioavailability (Brickett et al., 1995; Kelsey et al., 2010). Among chemical agents, methyl bromide, formaldehyde or mercuric chloride are efficient microbial inhibitors (Trevors, 1996), but they contaminate the matrix with toxic residues, including metals, complexing agents, and oxidizing/reducing compounds, making them unsuitable for the investigation of contaminant dynamics, especially trace metals (Brickett et al., 1995).

Among chemical poisons, sodium azide $\left(\mathrm{NaN}_{3}\right)$ is a strong metabolic inhibitor of the respiratory chain (Lichstein and Soule, 1944), used in various matrices to prepare abiotic controls avoiding physicochemical alterations, especially when studying metal-polluted matrices. $\mathrm{NaN}_{3}$ is known to inhibit microbial growth and distinct microbial activities, such as MTBE degradation (Hanson et al., 1999), manganese-, iron-, and sulfur-oxidation in pure cultures and metal-contaminated river-sediments (Burton et al., 2009; Wang et al., 2009); PAH-degradation activity in wetland sediments (Beckles et al., 1998) and sulfate-reducing bacterial enrichment cultures (Tsai et al., 2009); mercury methylation and demethylation in lake sediments (Zhang and Planas, 1994). In these studies, $\mathrm{NaN}_{3}$ concentration usually ranged between 1 and $150 \mathrm{mM}$. However, the efficiency of $\mathrm{NaN}_{3}$ depends on its concentration and the environmental matrix properties, and few studies have quantified 
its inhibitory effect on microbial growth in marine matrices, especially in the presence of sediments.

The objective of this study is to evaluate the efficiency and the dose effect of $\mathrm{NaN}_{3}$ in inhibiting microbial growth and activity during resuspension of marine sediment in seawater. The susceptibility of microbial communities was compared under natural- and enriched-resource supply conditions, representative of normal and nutrient rich environments. Moreover, both free-living and sessile microbes were targeted since both life forms are known to occur naturally in marine environments.

Surface seawater and surface $(0-5 \mathrm{~cm})$ marine sediments were collected in the northern part of the multicontaminated Toulon Bay (France). The sampling procedure and sampling site characteristics (MIS station) are detailed elsewhere (Dang et al., 2015). Chemical and biological characteristics of water and sediment samples from the same sites at a similar period of the year were previously described (Misson et al., 2016, Coclet et al., submitted).

Sediments and sea water were aerobically mixed at a solid/liquid ratio of $30 \mathrm{~g} \mathrm{~L}^{-1}$ (wet weight). Thirty milliliters of the sediment suspension were incubated in sterile $50 \mathrm{~mL}$ tubes at ambient temperature, in the dark, under continuous overhead shaking ( $15 \mathrm{rpm}$, Heidolph Reax 20) during 11 days. Tubes were frequently opened under sterile conditions to ensure sufficient oxygenation along the experiment. Two series of experiments were conducted. First, the inhibitory effect of a common $\mathrm{NaN}_{3}$ concentration $(50 \mathrm{mM})$ was evaluated under natural resource conditions, by comparison with unpoisoned control. Secondly, the inhibitory effect of low $(5 \mathrm{mM})$ and high $(50 \mathrm{mM}) \mathrm{NaN}_{3}$ concentrations was evaluated under growth-promoting conditions (addition of $0.1 \times$ of Luria-Bertani (LB) broth and $1 \mathrm{~g} \mathrm{~L}^{-1}$ glucose), by comparison with unpoisoned control under the same nutrient-rich conditions. Each condition was done in triplicate. $\mathrm{pH}$ was measured in the suspension at the beginning $\left(T_{0}\right)$, after $2 \mathrm{~h}, 4$ days, and at the end $\left(\mathrm{T}_{\mathrm{f}}\right)$ of the incubations using a Cyberscan 510 (Eutech) probe.

In the suspended phase, free-living prokaryote abundance and activity (esterase assay) were estimated at $\mathrm{T}_{0}$, after $2 \mathrm{~h}, 4$ days and at $\mathrm{T}_{\mathrm{f}}$ by flow cytometry. One $\mathrm{mL}$ sediment suspension aliquots were centrifuged $\left(2^{\prime}, 800 \mathrm{~g}\right)$ to remove the largest particles. The supernatant was analyzed with an Accuri C6 flow cytometer (BD), total heterotrophic prokaryotes being enumerated after SYBR green staining $(0.5 \times$ final concentration) and active prokaryotes being enumerated after CFDA staining (10 $\mu \mathrm{M}$ final concentration) according to previous work (Grégori et al., 2001).

For sedimentary microbial abundance quantification, $20 \mathrm{~mL}$-samples of the sediment suspension were collected at initial and final days from all incubations, centrifuged at $10.000 \mathrm{rpm}$ for $15 \mathrm{~min}$, and the pellets were stored at $-20{ }^{\circ} \mathrm{C}$ until DNA extraction. Total genomic DNA

\section{A. Without nutrient addition}

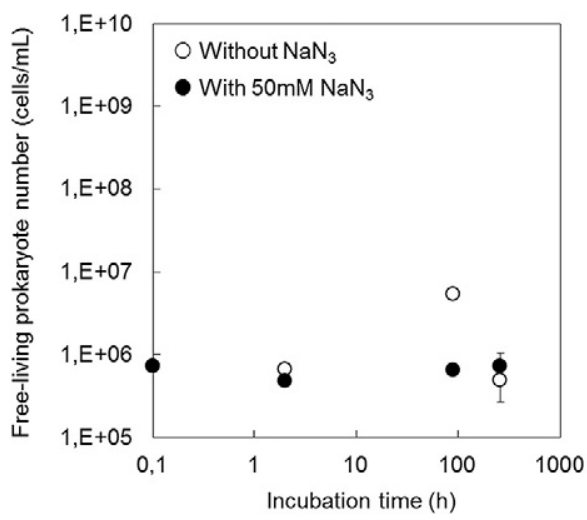

was extracted from the pellets (app. $325 \mathrm{mg}$ ) with PowerSoil DNA Isolation Kit (MoBio Laboratories, Carlsbad, CA, US). Bacterial abundances were quantified by real-time PCR (CFX96, Bio-Rad Laboratories) of 16S rRNA gene fragments, with GoTaq qPCR Master Mix (Promega), using GML5F and Univ516 primers, as described previously (Duran et al., 2015).

Under natural resource conditions, and without addition of $\mathrm{NaN}_{3}$, the abundance of free-living prokaryotes in the suspended phase showed an 8-fold increase compared to $\mathrm{T}_{0}$ during the first four days, prior to returning to the initial level by $\mathrm{T}_{\mathrm{f}}$ (Fig. $1 \mathrm{~A}$ ), probably as a result of resource depletion or predator-prey succession (Sauret et al., 2015). The number of CFDA-degrading (active) free-living prokaryotes followed a similar pattern, although their transient increase was limited to 4fold (Supplementary information SI.1A). In the sedimentary phase, the number of bacterial $16 \mathrm{~S}$ rRNA gene copies increased by a factor of 9 between $\mathrm{T}_{0}$ and $\mathrm{T}_{\mathrm{f}}$ (Fig. 2), confirming global bacterial growth and indicating different dynamics between free-living and sessile prokaryotes.

When $\mathrm{NaN}_{3}$ was added at $50 \mathrm{mM}$, the growth of free-living prokaryotes was inhibited throughout the experiment (Fig. 1A) and free-living active cells were less numerous (4-fold decrease compared to $T_{0}$ ) as soon as $2 \mathrm{~h}$ after poisoning, maintaining this low level until the end of incubation (Fig. SI.1A). Moreover, sessile bacterial 16S rRNA gene copy number demonstrated a 4 -fold decrease between $\mathrm{T}_{0}$ and $\mathrm{T}_{\mathrm{f}}$ (Fig. 2). Therefore, under natural resource conditions, $\mathrm{NaN}_{3}$ at $50 \mathrm{mM}$ was found to efficiently inhibit microbial growth and activity in both suspended and sediment phases.

However, $\mathrm{NaN}_{3}$ efficiency required further evaluation under rich substrate conditions favoring microbial growth. Depending on the matrix properties, high $\mathrm{NaN}_{3}$ concentration may induce physicochemical interactions with contaminant dynamics, through -for example- abiotic $\mathrm{CO}_{2}$ and volatile acid evolution as well as $\mathrm{pH}$ rise, as evidenced in soil when $\mathrm{NaN}_{3}$ concentration exceeded $77 \mathrm{mM}$ (Rozycki and Bartha, 1981). It is thus important to assess if lower $\mathrm{NaN}_{3}$ concentrations have sufficient inhibitory effect, even under rapid growth-promoting conditions.

Under simulated nutrient rich conditions (LB and glucose addition), microbial growth was strongly enhanced in both suspended and sediment compartments, in absence of $\mathrm{NaN}_{3}$ poisoning. A continuous increase was observed for both total (Fig. 1B) and active (Fig. SI·1B) free-living cell abundance, exceeding 1000-fold enrichments between $\mathrm{T}_{0}$ and $\mathrm{T}_{\mathrm{f}}$. Sessile bacteria 16S rRNA gene copy number also increased by a factor larger than 1000 between $\mathrm{T}_{0}$ and $\mathrm{T}_{\mathrm{f}}$ (Fig. 2).

Under high resource availability, the use of $5 \mathrm{mM} \mathrm{NaN}_{3}$ (i.e. in the low range of reported concentrations in the literature) reduced the planktonic and sessile biomass growth (by a factor 100 compared to the unpoisoned condition) but was not sufficient to completely inhibit

B. With LB and glucose addition

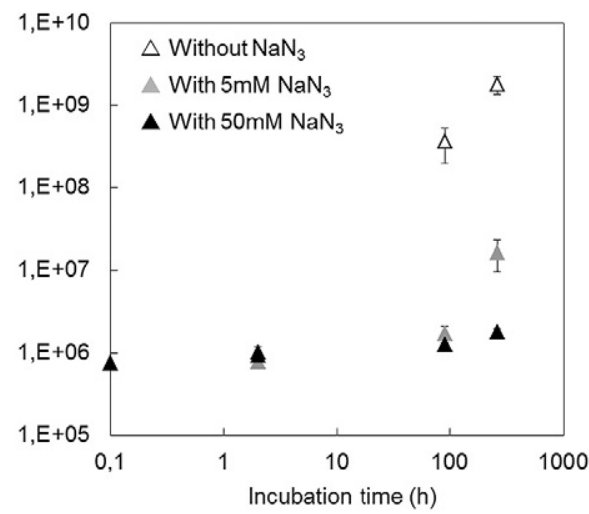

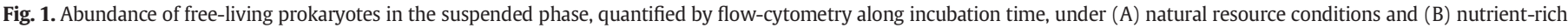

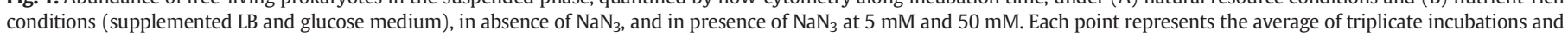
error bars represent standard deviations. 


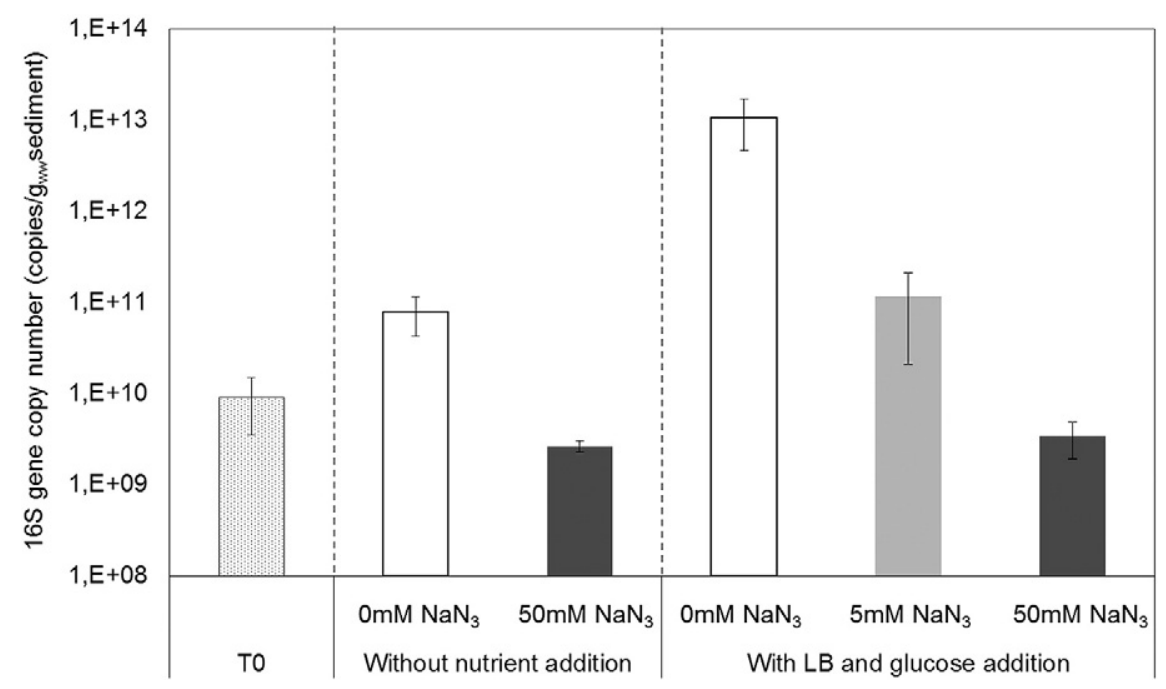

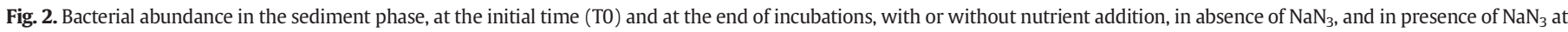

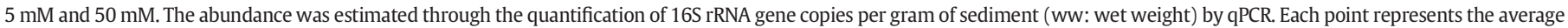
of triplicate incubations and error bars represent standard deviations.

microbial growth and activity in either suspended or sediment phases. Indeed, growth was only slowed down and delayed by the addition of $\mathrm{NaN}_{3}$ at $5 \mathrm{mM}$, which still allowed a 22-fold increase of free-living prokaryote abundance (Fig. 1B), a 50-fold increase in active free-living cell number (Fig. SI-1B), and a 12-fold increase of bacterial 16S rRNA gene copy number, between $\mathrm{T}_{0}$ and $\mathrm{T}_{\mathrm{f}}$ (Fig. 2). The efficiency of $\mathrm{NaN}_{3}$ is reported to be dose-dependent: it was for example less efficient (at $20 \mathrm{mM}$ ) than other chemicals (acetonitrile) to inhibit dehydrogenase activity in river sediments (Mosher et al., 2003), while it had only a partial inhibition effect (at $1 \mathrm{mM}$ ) on manganese reduction in pure bacterial cultures, lower than other metabolic poisons (formaldehyde, antimycin, CCCP) under anaerobic conditions (Myers and Nealson, 1988).

By contrast, the addition of $50 \mathrm{mM} \mathrm{NaN}_{3}$ resulted in a 1000-fold reduction of planktonic and sessile bacterial growth compared to the unpoisoned condition. Despite growth-favoring conditions, the addition of $50 \mathrm{mM} \mathrm{NaN}_{3}$ led to a stable number of free-living active cells during the whole incubation (Fig. SI·1B) and a slight (3-fold) decrease of sessile bacterial $16 \mathrm{~S}$ rRNA gene copy number between $T_{0}$ and $T_{f}$ (Fig. 2). However, a minor (2-fold) increase of free-living prokaryote abundance was still observed during the incubation (Fig. 1B). The fact that the abundance of sessile bacteria not only remained constant (indicating impediment of growth), but in some cases decreased during the incubation (in presence of $\mathrm{NaN}_{3}$ at $50 \mathrm{mM}$, independently of the substrate conditions) suggests that $\mathrm{NaN}_{3}$ not only suppressed microbial growth but may also have lysed a fraction of the initial indigenous cells. When considering the active fraction of free-living prokaryotes, $\mathrm{NaN}_{3}$ (at both tested concentrations) seemed to have a stronger transient inhibitory effect at short term, i.e. resulting in a loss of active cells (by a factor 4 to 14) during the first two hours, before further increase (Supplementary Fig. S1).

In absence of $\mathrm{NaN}_{3}, \mathrm{pH}$ dropped from 8.3 , at $\mathrm{T}_{0}$, to $7.3 \pm 0.2$ and $7.6 \pm 0.2$, at $\mathrm{T}_{\mathrm{f}}$ (respectively with and without nutrient enrichment), as a result of microbial activity. Under growth favoring conditions, the addition of $5 \mathrm{mM} \mathrm{NaN}_{3}$ did not modify the amplitude of $\mathrm{pH}$ drop (decreasing to $7.2 \pm 0.1$ at $\mathrm{T}_{\mathrm{f}}$ ), while the addition of $50 \mathrm{mM} \mathrm{NaN}_{3}$ resulted in a less marked pH decrease compared to the unpoisoned control (down to $7.7 \pm 0.0$ at $\mathrm{T}_{\mathrm{f}}$ ), thus confirming the partial efficiency of $5 \mathrm{mM}$ NaN3 and the better reduction of microbial activity in presence of $50 \mathrm{mM} \mathrm{NaN}_{3}$. The difference of $\mathrm{pH}$ between $\mathrm{T}_{0}$ and $50 \mathrm{mM} \mathrm{NaN}_{3}$ condition may be due to (i) residual microbial activity or (ii) abiotic effect of $\mathrm{NaN}_{3}$.
Thus, in nutrient rich environments, $50 \mathrm{mM} \mathrm{NaN}_{3}$ appears efficient for complete inhibition of growth of sessile bacteria over 11 days (contrary to $5 \mathrm{mM} \mathrm{NaN}_{3}$ ), but failed to totally inhibit free-living prokaryote growth, as a small fraction of free-living cells remained active and able to grow. Therefore, the use of $\mathrm{NaN}_{3}$ to perform abiotic controls in microcosm experiments appears feasible when employed at sufficiently high concentration ( $\geq 50 \mathrm{mM}$ ) for short term incubations, depending on resources availability. $\mathrm{NaN}_{3}$ poisoning is considered as relatively benign in terms of metal interactions and abiotic oxidation processes (precipitation, leaching...) even in metal-contaminated matrices (Neubauer et al., 2002; Rentz et al., 2007). Although the present study demonstrates the inhibition efficiency of $\mathrm{NaN}_{3}$ on microbial growth and activity, its potential physicochemical effects on the geochemistry of the samples should be further evaluated according to the targeted contaminant, the poison concentration, and the matrix properties. For example, $\mathrm{NaN}_{3}$ reacts chemically with some organic compounds, such as atrazine, and thus should not be used to prepare abiotic controls in atrazine degradation studies (Chefetz et al., 2006).

Supplementary data to this article can be found online at http://dx. doi.org/10.1016/j.mimet.2016.12.021.

\section{Acknowledgements}

This study was financially supported by the French Research Institute for Development (IRD) (ACTION SUD-MIO) and the MerMexWP3-C3A/MISTRALS research program (part of the international IMBER, LOICZ and SOLAS projects). The authors wish to thank Dr. C. Garnier, the French Navy and the LASEM for diving and sediment sampling assistance, as well as Sophie Guasco for technical support and Sean C. Smith for helpful correction of English wording.

\section{References}

Beckles, D.M., Ward, C.H., Hughes, J.B., 1998. Effect of mixtures of polycyclic aromatic hydrocarbons and sediments on fluoranthene biodegradation patterns. Environ. Toxicol. Chem. 17, 1246-1251.

Brickett, L.A., Hammack, R.W., Edenborn, H.M., 1995. Comparison of methods used to inhibit bacterial activity in sulfide ore bioleaching studies. Hydrometallurgy 39, 293-305.

Burton, E.D., Bush, R.T., Sullivan, L.A., Hocking, R.K., Mitchell, D.R.G., Johnston, S.G. Fitzpatrick, R.W., Raven, M., McClure, S., Jang, Y., 2009. Iron-monosulfide oxidation in natural sediments: resolving microbially mediated $\mathrm{S}$ transformations using XANES, electron microscopy, and selective extractions. Environ. Sci. Technol. 43 3128-3134. 
Chefetz, B., Stimler, K., Shechter, M., Drori, Y., 2006. Interactions of sodium azide with triazine herbicides: effect on sorption to soils. Chemosphere 65, 352-357.

Dang, D.H., Schäfer, J., Brach-Papa, C., Lenoble, V., Durrieu, G., Dutruch, L., Chiffoleau, J.F. Gonzalez, J.L., Blanc, G., Mullot, J.U., Mounier, S., Garnier, C., 2015. Evidencing the impact of coastal contaminated sediments on mussels through pb stable isotopes composition. Environ. Sci. Technol. 49, 11438-11448.

Duran, R., Bonin, P., Jezequel, R., Dubosc, K., Gassie, C., Terrisse, F., Abella, J., Cagnon, C., Militon, C., Michotey, V., Gilbert, F., Cuny, P., Cravo-Laureau, C., 2015. Effect of physical sediments reworking on hydrocarbon degradation and bacterial community structure in marine coastal sediments. Environ. Sci. Pollut. Res. 22, 15248-15259.

Egli, M., Mirabella, A., Kägi, B., Tomasone, R., Colorio, G., 2006. Influence of steam sterilisation on soil chemical characteristics, trace metals and clay mineralogy. Geoderma 131, 123-142.

Grégori, G., Citterio, S., Ghiani, A., Labra, M., Sgorbati, S., Brown, S., Denis, M., 2001. Resolution of viable and membrane-compromised bacteria in freshwater and marine waters based on analytical flow cytometry and nucleic acid double staining. Appl Environ. Microbiol. 67, 4662-4670.

Hanson, J.R., Ackerman, C.E., Scow, K.M., 1999. Biodegradation of methyl tert-butyl ether by a bacterial pure culture. Appl. Environ. Microbiol. 65, 4788-4792.

Kelsey, J.W., Slizovskiy, I.B., Peters, R.D., Melnick, A.M., 2010. Sterilization affects soil organic matter chemistry and bioaccumulation of spiked p,p'-DDE and anthracene by earthworms. Environ. Pollut. 158, 2251-2257.

Lichstein, H.C., Soule, M.H., 1944. Studies of the effect of sodium azide on microbic growth and respiration. I. The action of sodium azide on microbic growth. J. Bacteriol. 47, 239-251.

Misson, B., Garnier, C., Lauga, B., Dang, D.H., Ghiglione, J.F., Mullot, J.U., Duran, R., Pringault, O., 2016. Chemical multi-contamination drives benthic prokaryotic diversity in the anthropized Toulon Bay. Sci. Total Environ. 556, 319-329.

Mosher, J.J., Levison, B.S., Johnston, C.G., 2003. A simplified dehydrogenase enzyme assay in contaminated sediment using 2-(p-iodophenyl)-3(p-nitrophenyl)-5-phenyl tetrazolium chloride. J. Microbiol. Methods 53, 411-415.

Myers, C.R., Nealson, K.H., 1988. Bacterial manganese reduction and growth withmanganese oxide as the sole electron acceptor. Science 240, 1319-1321.

Neubauer, S.C., Emerson, D., Megonigal, J.P., 2002. Life at the energetic edge: kinetics of circumneutral iron oxidation by lithotrophic iron-oxidizing bacteria isolated from the wetland-plant rhizosphere. Appl. Environ. Microbiol. 68, 3988-3995.
Quéméneur, M., Garrido, F., Billard, P., Breeze, D., Leyval, C., Jauzein, M., Joulian, C., 2016. Bacterial community structure and functional arrA gene diversity associated with arsenic release and reduction in an industrially contaminated soil. Geomicrobiol J. 33, 839-849.

Ramsay, A.J., Bawden, A.D., 1983. Effect of sterilization and storage on respiration, nitrogen status and direct counts of soil bacteria using acridine orange. Soil Biol. Biochem. 15, 263-268.

Rentz, J.A., Kraiya, C., Luther III, G.W., Emerson, D., 2007. Control of ferrous iron oxidation within circumneutral microbial iron mats by cellular activity and autocatalysis. Environ. Sci. Technol. 41, 6084-6089.

Rozycki, M., Bartha, R., 1981. Problems associated with the use of azide as an inhibitor of microbial activity in soil. Appl. Environ. Microbiol. 41, 833-836.

Sauret, C., Böttjer, D., Talarmin, A., Guigue, C., Conan, P., Pujo-Pay, M., Ghiglione, J.F., 2015. Top-down control of diesel-degrading prokaryotic communities. Microb. Ecol. 70, 445-458.

Senko, J.M., Wanjugi, P., Lucas, M., Bruns, M.A., Burgos, W.D., 2008. Characterization of $\mathrm{Fe}(\mathrm{II})$ oxidizing bacterial activities and communities at two acidic Appalachian coalmine drainage-impacted sites. ISME J. 2, 1134-1145.

Bank, T.L., Kukkadapu, R.K., Madden, A.S., Ginder-Vogel, M.A., Baldwin, M.E., Jardine, P.M., 2008. Effects of gamma-sterilization on the physico-chemical properties of natural sediments. Chem. Geol. 251, 1-7.

Trevors, J.T., 1996. Sterilization and inhibition of microbial activity in soil. J. Microbiol. Methods 26, 53-59.

Tsai, J.C., Kumar, M., Lin, J.G., 2009. Anaerobic biotransformation of fluorene and phenanthrene by sulfate-reducing bacteria and identification of biotransformation pathway. J. Hazard. Mater. 164, 847-855.

Wang, W., Shao, Z., Liu, Y., Wang, G., 2009. Removal of multi-heavy metals using biogenic manganese oxides generated by a deep-sea sedimentary bacterium Brachybacterium sp. strain Mn32. Microbiology 155, 1989-1996.

Zhang, L., Planas, D., 1994. Biotic and abiotic mercury methylation and demethylation in sediments. Bull. Environ. Contam. Toxicol. 52, 691-698. 